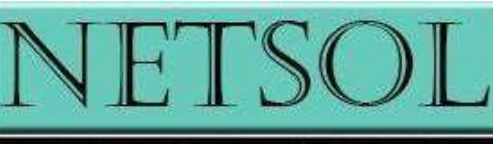

NEW TRENDS IN SOCIAL AND LIBERAL SCIENCES

An Interdisciplinary Journal

http://www.netsoljournal.net/

Volume 5, Issue 2, pp.1-29, Fall 2020

https://doi.org/10.24819/netsol2020.05

Date Submitted: April 21, 2020

Date Accepted: October 17, 2020

\title{
Keys to Human Development: The Baltic Miracle
}

\section{Walter C. Clemens, Jr. Boston University, Professor Emeritus}

\begin{abstract}
The three Baltic republics-Estonia, Latvia, Lithuania - are the only units of the former Soviet Union to deal effectively with the complex challenges of transitioning to free market democracy with advancing levels of human development. These countries have developed high levels of societal fitnessdefined in complexity science as the ability to cope with multifaceted challenges and opportunities. What are the sources of these achievements? Many factors intertwined to produce what some call the "Baltic miracle." One key element has been the three revolutions stemming from the Protestant mandate to read and discuss the Bible: mass literacy, free thought and repression, and respect for individual dignity. Protestant influences were strongest in what is now Estonia and Latvia, but they reached Lithuania as well. Religiosity in now low in the Baltic republics, as in the Sweden that once nurtured both Christianity and literacy in its Baltic provinces. But the sparks it ignited in centuries past have shaped the rationalist and humanistic ethos of the region. Religion, of course, is just one of the European influences that conditioned economic and other cultural development in the region. But the dates when the Bible reached all of Europe in the vernacular are strong predictors of human development today. Balts also gained from not being occupied by the Golden Horde. On the other hand, they had to overcome several centuries of Russian and then Soviet domination. Fifty years of Communist rule dimmed but did not extinguish the positive qualities that reemerged with great vitality in the late $20^{\text {th }}$ and early $21^{\text {st }}$ centuries. The Baltic transformations were not "managed" from above or from outside - not from Brussels, not from Washington. They were encouraged and supported by Sweden and other European powers, but each transformation emerged from the bottom-up rather than from the top-down or from outside-in. Balts acted synergistically to contribute to the self-organization that is crucial to meeting complex challenges.
\end{abstract}

Key Words: Complexity Science, Societal Fitness, Baltics, Estonia, Latvia, Lithuania

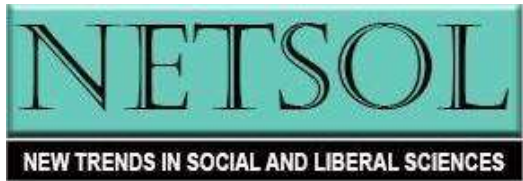




\section{The Cure at Troy}

Human beings suffer.

They torture one another.

They get hurt and get hard.

No poem or play or song

Can fully right a wrong

Inflicted and endured.

History says, "Don't hope

On this side of the grave."

But then, once in a lifetime

The longed for tidal wave

Of justice can rise up

And hope and history rhyme.

So hope for a great sea-change

On the far side of revenge.

Believe that a further shore
Is reachable from here.

Believe in miracles.

And cures and healing wells.

Call miracle self-healing,

The utter self revealing

Double-take of feeling.

If there's fire on the mountain

And lightening and storm

And a god speaks from the sky

That means someone is hearing

The outcry and the birth-cry

Of new life at its term.

It means once in a lifetime

That justice can rise up

And hope and history rhyme.

Seamus Heaney_from his verse adaptation in 1990 of Sophocles’ play Philoctetes

\section{A Many-sided Wonder}

The transformation of Estonia, Latvia, and Lithuania in the late $20^{\text {th }}$ and early $21^{\text {st }}$ century is a process that evokes awe and astonishment. ${ }^{1}$ The essence of the Baltic miracle is that Baltic peoples began to cope effectively with complex challenges facing them at home and abroad. Tested, they responded creatively and effectively to difficult problems. They developed high levels of societal fitness. ${ }^{2}$ Never before had Balts coped so well with complexity. Their achievements suggest lessons for human development elsewhere. ${ }^{3}$ Unlike the "seven wonders" of the ancient world or the London bridge (numbered among the world's wonders in the 17 th century), the Baltic miracle of the late 20th and early $21^{\text {st }}$ centuries did not rest on stones but on the fusion and combustion of intangible human qualities. It was more remarkable than Sir Isaac Newton — called

${ }^{1}$ Miracle comes from Latin mirari- to marvel; wonder derives from German Wunder and Old Norse undr. Russians referred to the peoples west of Pskov as chudskie-wondrous strange. When Germans ruled "Ostland," however, they saw their subjects as less-than-human "undeutsche."

${ }^{2}$ Societal fitness here is not the "fitness" in Herbert Spencer's racially tinged sense of "survival of the fittest." ${ }^{3}$ The present analysis mentions Russia and other Baltic coastal states - Germany, Sweden, Finland, Polandonly in passing. For the broader picture, see the author's The Baltic Transformed: Complexity Theory and European Security (Lanham MD: Rowman \& Littlefield, 2001).

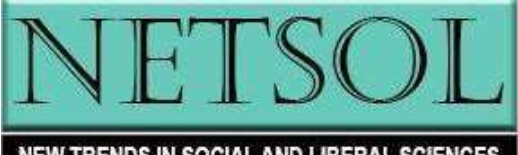

NEW TRENDS IN SOCIAL AND LIBERAL SCIENCES 
a "miracle" of his age - because it entailed not just individual development but the interactions of many individuals.

\section{Human Development in the Baltic Republics}

The Baltic miracle was and continues to be a many-sided process. First, three small peoples challenged imperial rule from Moscow and regained independence from a mighty empire. Indeed, the three Baltic Davids helped to slay the Soviet Goliath. They inspired Ukraine, Russia, Belarus, and Kazakhstan to break from the Soviet empire; the other union-republics followed suit as the empire collapsed-some with great trepidation. ${ }^{4}$

Second, in the late 20th and first decades of the $21^{\text {th }}$ century, Estonia, Latvia, and Lithuania were the only units of the former Soviet Union to make substantial headway in what the United Nations calls "human development" and in the difficult transitions to political democracy, a market economy, and constructive participation in the international community. These transitions took place at different rates in each Baltic republic, but their rapid pace disproved the claim of one expert that "transition to a fuller market and more comprehensive democracy is always evolutionary and managed and takes decades." ${ }^{5}$ Sweden and other outside actors encouraged and gave some support for these transitions. Still, the Baltic transformations did not require decades, and none was "managed" from above or from outside - not from Brussels, not from Washington. (The major U.S. contribution was its refusal since 1940 to recognize Soviet ownership of the Baltic republics, an example followed by most of Europe except Sweden.) Each transformation emerged from the bottom-up rather than from the top-down or from outside-in. Indeed, soon after it regained independence, Estonia's decision to peg its currency to the German Mark ran against advice from the International Monetary Fund.

Societal fitness can be measured by the same indicators used by UN Human Development Programme. Its Human Development Index (HDI) assesses each country's attainments in physical health, education, purchasing power, gender equality and other indicators of justice. The HDI scores aggregate measures of income, health, and education, where Norway has enjoyed the highest score since 2005. The rankings of most countries have vacillated over the years (in part because UN statistical methods changed), but the secular trends are clear. Estonia moved from $43^{\text {rd }}$ in the world in 1995 to $30^{\text {th }}$ in 2019 (just below Italy); Lithuania, from $71^{\text {st }}$ to $34^{\text {th }}$ (just behind Poland); Latvia, from $48^{\text {th }}$ to $39^{\text {th }}$ (just above Portugal, Brunei and Hungary). Russia moved only from $52^{\text {nd }}$ to $49^{\text {th }}$. Two other former Soviet Union-republics, Belarus and Kazakhstan, tied at $50^{\text {th }}$. Of the former Soviet allies in Eastern Europe, Czechia ranked highest $-26^{\text {th }}$, followed by Poland, $32^{\text {nd }}$; and Hungary, $43^{\text {rd }}$. Less repressed than the former Baltic republics under Moscow's rule, the former Soviet satellites faced fewer challenges. Due mainly to polarized politics and social malaise, the United States declined from $2^{\text {nd }}$ to $15^{\text {th }} .6$

${ }^{4}$ Walter C. Clemens, Jr., Baltic Independence and Russian Empire (New York: St. Martin's, 1991).

${ }^{5}$ Jerry F. Hough, Democratization and Revolution in the USSR, 1985-1991 (Washington, D.C.: Brookings Institution Press, 1997), p. 490.

${ }^{6}$ United Nations Development Programme, Human Development Report 2019:

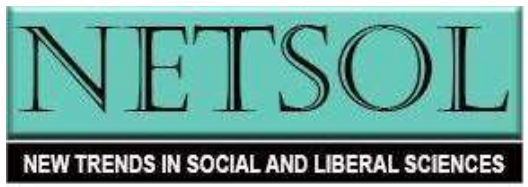


Comparing the quality of HDI indicators across the Baltic, Estonia led in 12 dimensions; Latvia in 8; Lithuania in 5. With respect to environmental sustainability, however, Lithuania did better than Estonia or Latvia. ${ }^{7}$ Between 1990 and 2018, Estonia's life expectancy at birth increased from 69.4 to 78.6; expected years of schooling, from 13.1 to 16.1; mean years of schooling, from 9.3 to 13.0; GNI per capita (in 2011 PPP\$), from $\$ 15,020$ to $\$ 30,379$. While Estonia's HDI rating increased significantly, the HDI increases for the Republic of Korea and Czechia were even steeper. While life expectancy in Estonia of 78.6 is close to the OECD average 80.4, Estonia's GNI per capita is one-fourth lower than the OECD average. The Gender Development Index showed that females in each Baltic state enjoyed slightly higher HDI values than males, while the EU average favored males. If Estonia's performance in indicators of socioeconomic sustainability is compared with that Cyprus and Slovenia, similar in population and income, Estonia does better. Lithuania's trends are also positive.

Could we assume that the qualities that nourish human development also tend to limit Covid19 infections and deaths? This correlation approximated outcomes in the Baltic region but not across Europe. The three Baltic countries have so far had low rates of infections - in the same ballpark as Norway and Finland. But Sweden and the United Kingdom, high on the HDI, had much worse rates, as did lower placed Belarus and Russia. Here are the number of cases per 100,000 population as of September 30, 2020: Latvia, 91; Lithuania, 164; Finland, 179; Poland, 237; Estonia, 250; Norway, 259; Germany, 348; Ukraine, 466; United Kingdom, 669; Russian Federation, 801; France, 822; Belarus, 828; Sweden, 904.

Was it the case that a small population assured a lower infection rate? No. Europe's highest rates were in Montenegro, 1,699, and Armenia, 1,687. Europe's largest country, Germany, suffered fewer cases than smaller France and the United Kingdom. The smallest Baltic state, Estonia, had a much higher rate than the largest, Lithuania. In the United States, small Vermont and Maine had the lowest infection rates, but the very smallest state Rhode Island had a rate ten times higher than Vermont, which was higher than in the largest state, California. Adding to the complexity, one of the world's most affluent countries, the United States, led the world in total cases and deaths. ${ }^{8}$

\section{Education and Income}

Rates of education (years of schooling) have converged in the Baltic region since the mid1990s. But PPP income (purchasing power parity) has varied a great deal, helping to explain ups and downs in HDI rankings. The Baltic economies were in free fall from 1991 to 1995, when they returned to economic growth. Their economies grew soundly from 1996 to 1998, but the Russian financial crash of 1998 wiped out their growth again. From 2000 to 2008, the three Baltic economies grew at an average of 8-9 percent a year. But all three Baltic countries were hit hard

http://hdr.undp.org/sites/default/files/hdr2019.pdf [p. 304] (accessed 10/11/20).

${ }^{7}$ http://hdr.undp.org/sites/all/themes/hdr_theme/country-notes/LVA.pdf;

http://hdr.undp.org/sites/all/themes/hdr_theme/country-notes/EST.pdf;

http://hdr.undp.org/sites/all/themes/hdr theme/country-notes/LTU.pdf (accessed 9/30/20).

${ }_{8}^{8}$ Data from the European Centre for Disease Prevention and Control and STATISTA (accessed 10/1//20).

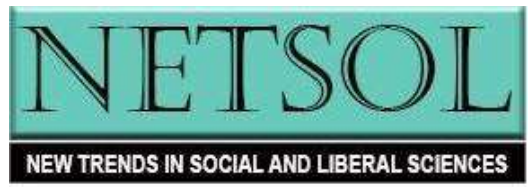


by the liquidity freeze that followed the bankruptcy of Lehman Brothers in 2008. In 2009, output in all three countries plummeted at a double-digit rate. All three reacted as they had done in the early 1990s, with radical and front-loaded fiscal adjustment accompanied by structural reforms; and they succeeded once again. From 2011 to 2014, the three Baltic economies grew at an average rate of 4.1 percent compared with only 0.7 percent for the European Union as a whole. ${ }^{9}$ The following two figures highlight the patterns. ${ }^{10}$

Fig. 1 GDP growth, Baltic states and the European Union 15, 1995-2016, in \% per year

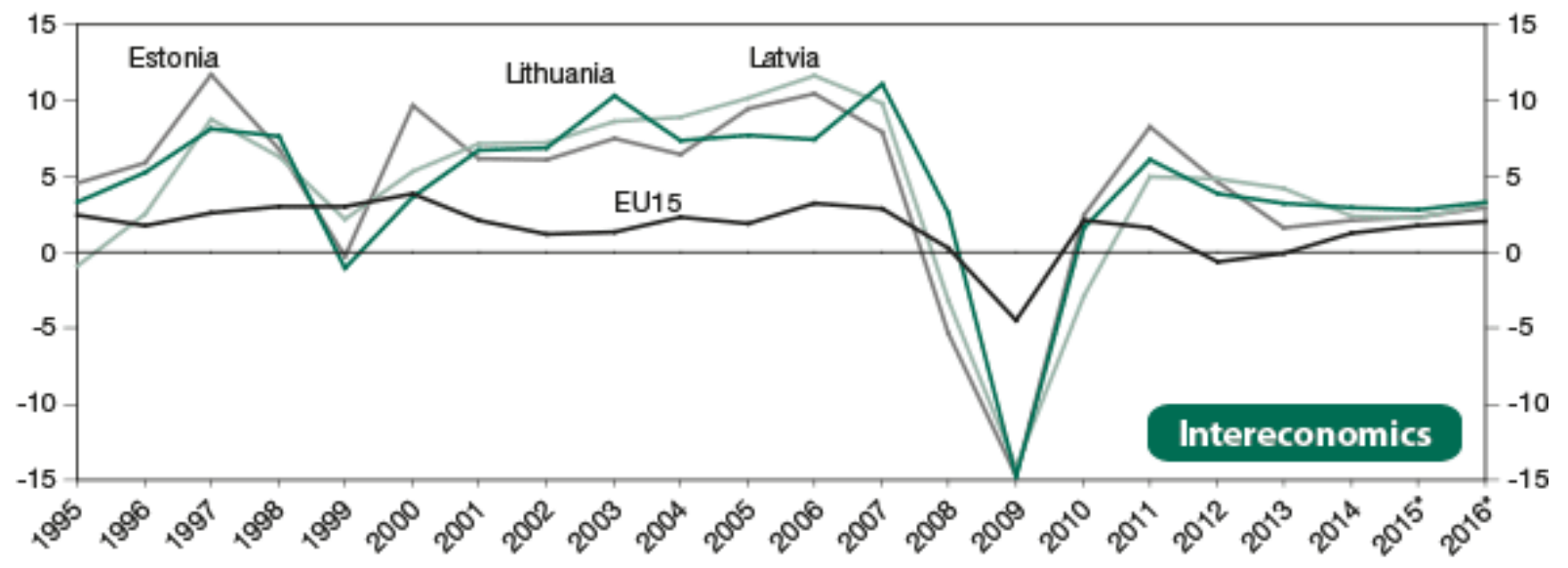

We see that the Baltic economies fell more sharply than other EU economies in 2008-2009, but they recovered quickly.

${ }^{9}$ Anders Åslund, "The Baltic Tigers: Past, Present and Future Why Have the Baltic Tigers Been So Successful?" CESifo Forum 4/2015 (December) at https://www.ifo.de/DocDL/forum-2015-4-aslund-baltictiger-december.pdf

${ }^{10}$ Karsten Staehr, "Economic Growth and Convergence in the Baltic States: Caught in a Middle-Income Trap?" Intereconomics (2015) 50, 5: 274-280.

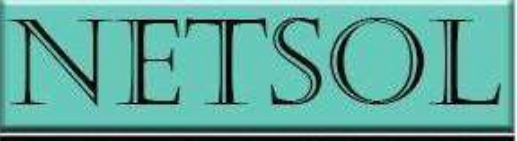

NEW TRENDS IN SOCIAL AND LIBERAL SCIENCES 
Fig. 2 GDP per capita (PPS), Baltic states, EU15 and Sweden, 1995-2014 (Index: USA = 100)

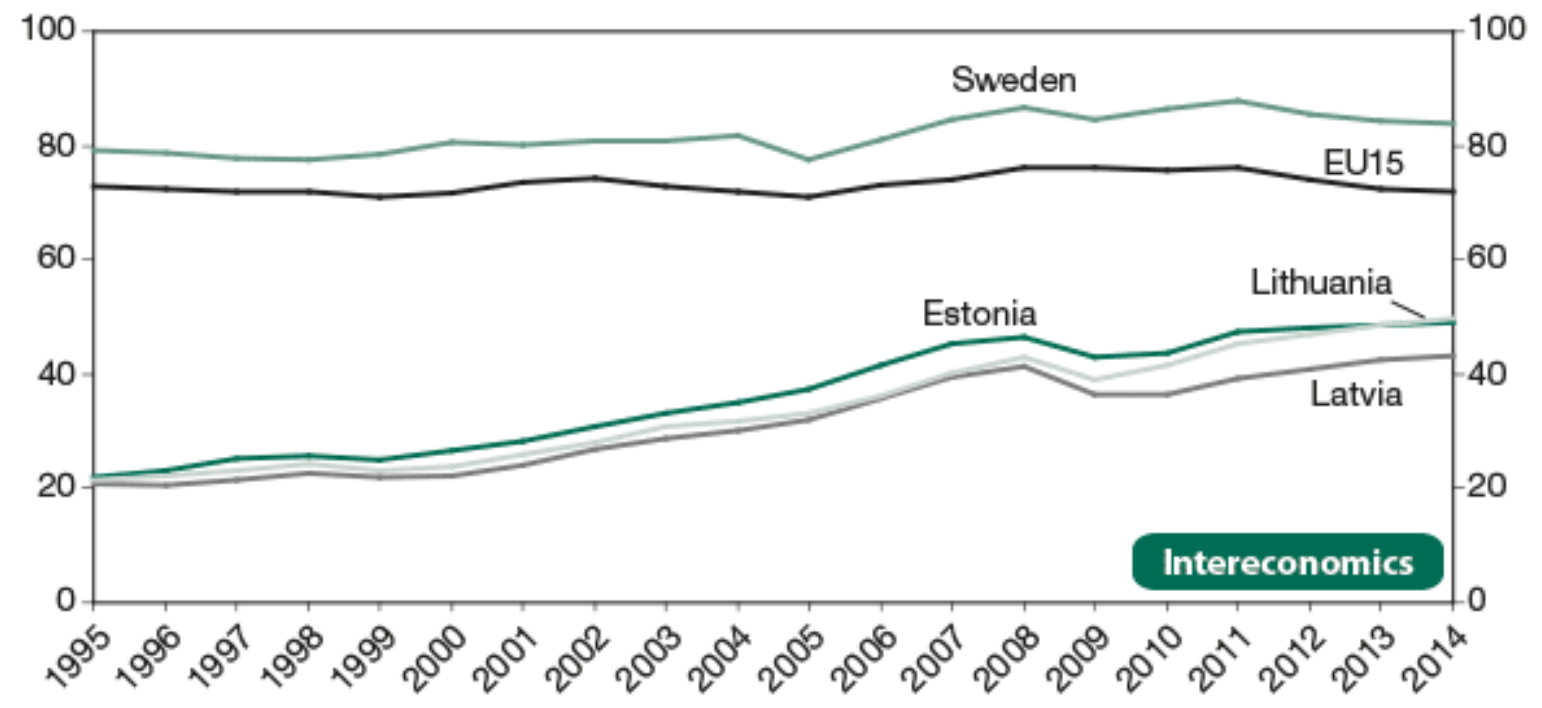

We see in Figure 2 that after setbacks in 2008-2009, per capita incomes in the Baltic republics were approaching the EU average and reached nearly half the United States level.

Estonia's focus on the IT sector and the startup world has contributed to the high-income economy that before Covid-19, it was among the fastest growing in the European Union. Estonian startups received more than $\$ 300$ million from foreign investors in 2018. A study of Estonia by Swedbank in 2018 showed that rapid wage growth exceeded rising apartment prices and interest rates. ${ }^{11}$

The big picture is that from 1990 to 2018, the GDP of Estonia grew by 592\%, Lithuania by $577 \%$, and Latvia by 502\%. (Poland led in Eastern Europe-788\%, while Croatia grew the least-172\%.) In this period the life expectancy for Estonians increased by 8.2 years; for Latvians, by 5.4 years; and for Lithuanians, by 3.5years. Total populations decreased in all three republics from 1990-91 to 2019-20: in Estonia, from 1,565,000 to 1,327,000; Latvia, from 2,640,000 to 1,886,000; Lithuania, from 3,696,000 to 2,760,000. Estonia experienced a one percent uptick from 2019 to 2020 but Latvia, a one percent decline. ${ }^{12}$ Many factors were at work including modernist concerns about the costs of a good life, out migration to the Slavic countries, and a high suicide rate in Lithuania, especially among older men in rural areas.

11“The economy in the Baltic states keeps growing and here's why," Reinvest 24 (January 21, 2019) at https://blog.reinvest24.com/2019/the-economy-in-the-baltic-states-keeps-growing-and-heres-why/ (accessed $10 / 11 / 20)$.

${ }^{12}$ Analysis of World Bank statistics by Shaun Walker, "'This is the golden age': eastern Europe's extraordinary 30-year revival," The Guardian, October 26, 2019. Population trends to 2020 are based on United Nations statistics.

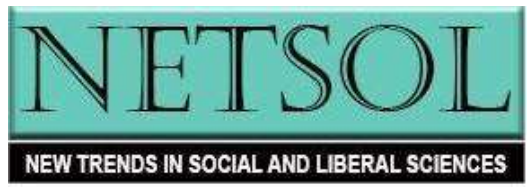


Income inequality persisted, but human development in the Baltic region was less unequal than the EU average. When discounted for inequality, the HDI for Lithuania lost 10.9\%; Latvia, 9.1\%; Estonia, 7.2\% - compared with average loss of 9.4\% in the EU. The Gini Index for all three Baltic republics in 2018 was in the mid-30s - higher than in Germany but much lower than in the United States. The Baltic states are the only former Soviet Union-republics to join the European Union (2003) and NATO (2004), bringing the Western alliance up to Russia's border at Kaliningrad. Czechoslovakia and most members of the erstwhile Warsaw Pact did so. However, Russia did join the Council of Europe in 1996, three years after the Baltic republics. Even though small and relatively poor in natural resources, the Baltic republics sharply reduced their multifaceted dependency on Russia, built up over many generations. They moved rapidly from energy dependence on Russia to energy interdependence with Russia and the West. They were the only former Soviet republics never to join the Russian-dominated Commonwealth of Independent States.

The Baltic republics' performance was more astonishing than Germany's "economic miracle" (Wirtschaftswunder) in the 1950s. Like Japan, Germany merely resumed after World War II an economic ascent launched in the previous century from very strong foundations. Germany's previous experience with self-rule was also far stronger than that of the Baltic peoples, who had been repressed by foreigners for centuries except in the 1920s and 1930s. The Baltic transformations were also more remarkable than those of Poland, Hungary, and the Czech Republic after the Soviet breakup. None of those countries lost its sovereignty to Soviet rule; each had richer natural resources; each experimented with economic and political reforms for decades before the Soviet collapse; each attracted more attention and investment from Western governments and businesses. Baltic performance resembled far more the boot-strapped "East Asian miracle."

Not only did Balts manage to pull away from Soviet domination using nonviolent means, but - after independence was achieved - they avoided serious communal violence. So far as known, fewer than twenty Balts (all Lithuanians) and no Soviet troops or Slavic settlers died in the 1980s as the Baltic republics broke from the Soviet rule. In the 1990s no deaths or violent conflicts due to ethnic differences were reported in the Baltic republics, even though native and Slavic-speaking communities felt many grievances toward each other. There were many gang fights, extortionist murders, and suicides in the Baltics; anti-Semites desecrated Jewish synagogues and (in April 1999) the Holocaust memorial in Riga; some Balts violated Soviet Army cemeteries; still, there was little ethnic violence. The near absence of communal fighting in the Baltic countries at the end of the 20th century contrasted not only with many other parts of the USSR (for example, Tajikistan) and the former Yugoslavia (Croatia, Bosnia, Kosovo) but also with racial strife in the United States, the United Kingdom, Germany, and France. despite the potential for ethnic discord between native Balts and Slavic settlers, each Baltic republic developed a comity of relative social harmony. ${ }^{13}$

\footnotetext{
${ }^{13}$ The word "comity" probably springs from the same root as "miracle." Miracle derives from the IndoEuropean smei for smile. Smei plus the suffix ro gives us smei-ro or miracle — an event, perhaps, that makes us smile. Add the prefix kom (as in Latin cum, together) to smei and the result is comity-a people that smiles together. American Heritage Dictionary of the English Language (3d ed.; Boston: Houghton-Mifflin, 1992).
}




How and why did all this happen? Let us review some candidate explanations.

\section{Contending Concepts and Explanations}

\section{History}

Did the Baltic miracle of the late 20th century take place despite or thanks to history? There were many previous wonders on the amber coast-more amazing because they were achieved in a milieu of long winters, cold rain and fog, frozen or rough seas, and often rocky soil.

- During the "Viking Age" (circa 793-1066) small bands of Scandinavian Vikings transformed Russia, Sicily, Normandy, the British Isles, and Iceland.

- Starting in the $12^{\text {th }}$ century German missionaries, knights, and merchants implanted their religion and dominated what is now Estonia and Latvia for many hundreds of years.

- Lithuanian tribes united and generated one of Europe's largest empires, the Polish-Lithuanian Commonwealth (1569) stretching from the Baltic to the Black Sea. When the Commonwealth was partitioned in the late $18^{\text {th }}$ century, however, most of Lithuania fell to Russia, which tried aggressively to impose its language and religion.

- From the early $17^{\text {th }}$ to the early $18^{\text {th }}$ century, another small state, Sweden, created and maintained a vast empire that included Finland and much of the Baltic's southern shore.

- In the early $18^{\text {th }}$ century Tsar Peter the Great converted the swampy Neva estuary into one of the world's great capitals, a window on Europe for Russia.

Even after Sweden and then Russia ruled the Baltic lands, the descendants of Teutonic knights and Hanseatic merchants continued to dominate the towns and manors of today's Estonia and Latvia until 1919-1920. A thousand years of history offered Balts more ground for despair than for pride or confidence. If great civilizations are creative responses to challenges, Balts usually failed the test. ${ }^{14}$ A long record showed that Baltic feuding and disunity often helped foreigners to divide and rule. The record brightened in the second half of the 19th century when, despite Russian repression, Finns, Estonians, Latvians, Lithuanians, and Poles experienced a cultural awakening — an amazing development after centuries of repression.

As the tsarist empire collapsed in World War I, each Baltic people claimed autonomy and then sovereignty. In 1919-1920 British and French armed forces fighting the Red Army helped Balts to defeat Soviet efforts to retake what Russians call Pribaltika - the Baltic littoral. But London and Paris did nothing to help Balts when Stalin and Hitler ended their independence in 1939-1940. Except for the fascist dictatorships, however, all European states, except Sweden, followed the U.S. lead and refused to recognize Soviet annexation of the Baltic republics. Nazi Germany seized the Baltics in 1941 but the Soviet Union took over again in 1945. As in 1940, the Soviets again arrested and sent to Siberia huge numbers of the Baltic republics' best and brightest. "Forest brethren" guerrillas in each Baltic country harassed Soviet occupiers until the mid-1950s.

${ }^{14}$ On the idea of an optimal response to an optimal challenge - not too little, not too much, see Arnold J. Toynbee, A Study of History, 12 volumes (New York: Oxford University Press, 1934-1961).

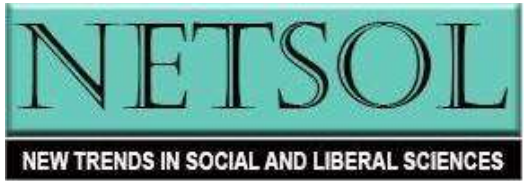


By the 1980s the three Baltic republics were among the most highly militarized regions of the USSR. Nonetheless Balts began to act as though they were free. In February 1991, Iceland became the first Western country to recognize Lithuania's independence and, in August, that of Estonia and Latvia. The Kremlin formally recognized their independence in September 1991 as did the George H. W. Bush administration, determined not to offend Moscow.

\section{Geography}

Did the Baltic miracle take place despite or thanks to Balts' strategic location and economic resources? To live at the crossroads of Europe and Eurasia presented major opportunities but even greater dangers. If peace prevailed and if Balts had been self-governing, their ports could have made them rich - even influential. But Balts' strategic location attracted not just traders but invaders. For 1000 years and more, invaders came from all directions seeking to make Baltic ports their own. Some succeeded for a time, depriving Balts of potential wealth. Besides their location and ports, Balts possessed other valuable resources - amber, furs, grain, even (in Estonia), oil shale and hydropower. Balts resources were probably better than those of small but prosperous Singapore, Hong Kong, and Taiwan. But Balts were resource-poor relative to Russia, Poland, or Germany. And Baltic weather offered more challenge than elixir.

\section{The West}

Did the Baltic miracle occur despite or thanks to the West? Western imperialists ruled the Baltic lands even longer than Russians. For more than five hundred years German-speaking merchants and artisans dominated political, economic, and cultural life in towns such as Reval (Tallinn) and Riga; German lords (seigneurs_-"Baltic barons") ruled the manors where they held Estonians and Latvians as serfs-sometimes breaking up families and selling them like cattle. German chroniclers wrote off Estonians, Latvians, and other subjected peoples as Undeutschenot-Germans, perhaps less than human. Similarly, Polish nobles, having polonized the Lithuanian nobility, viewed Lithuanian peasants with disdain.

On the other hand, the West brought Christianity, literacy, and nationalism. Armed monks and knights imposed Christianity on Estonians and Latvians in the $12^{\text {th }}$ and 13 th centuries. Pagan Lithuanians resisted but later accepted Catholicism as part of a strategic alliance with Poland. When Baltic barons chose Protestantism in the 16th century, their serfs had to follow. With Protestantism, however, came literacy. The first book published in Estonian was a Lutheran catechism printed in 1535. By the end of the 19th century most Estonians and Latvians were literate - unlike Russia, where illiteracy was common.

Even before the Reformation, the Baltic lands and peoples were shaped by Europe. For centuries Estonians and Latvians were ruled by Western clerics, knights, landlords, and Hanseatic merchants. Lithuanians rebuffed the Teutonic Knights but willingly joined with Poland in a "commonwealth" that became Europe's largest state. Just as French and German culture influenced Russian elites and educated strata (see the abundant references in Pushkin's Evgenii Onegin), so German influences_-not just Protestantism—shaped the Baltic. Unlike most Eastern Slavs, the Baltic lands were never occupied by Mongols or the Grand Dutchy of Moscow.

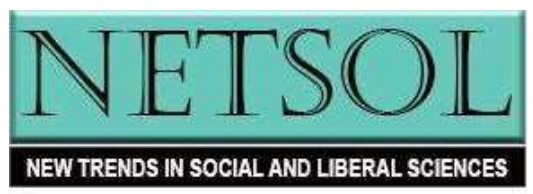


A key contribution to regional fitness was that most Balts experienced three revolutions generated by the Reformation. They became literate, developed habits of free expression, and came to see all persons as equal before God. This process began in the seventeenth century when Protestants in Sweden and, later, Prussia sponsored publication of Bibles in each Baltic language. ${ }^{15}$ Nothing like this happened in other parts of the tsarist or Soviet empires where Orthodoxy, Islam, or other religions prevailed. Similar transformations developed in parts of the Austro-Hungarian empire where Protestant influences became strong, as in Slovenia, or where Protestant competition pressured Catholic authorities to produce their own vernacular Bibles. The three revolutions proved to be an essential though not sufficient ingredient for high levels of human development. Nearly all the top twenty-five countries on the UN Human Development Index were shaped by these revolutions. 16

The religious wars were fought with ideas as well as soldiers. Lutheran and Calvinist ideas traveled eastward. Starting in the 1520s, the newly formed Duchy of Prussia promoted both Lutheranism and literacy among Poles and Lithuanians. Twelve years after the first book printed in Estonian, the first in Lithuanian was also a Lutheran catechism - published in 1547. Sunday gospels were published in Lithuanian in 1579 and the entire New Testament in 1701. Prussia established a university at Königsberg that trained Lithuanians for pastoral work. Most Poles and Lithuanians remained Catholic, however, thanks in part to a strong Counter Reformation mounted by Jesuits who, among other activities, established a university in Vilnius in the 1570s. Still, for the next three centuries Germanic Prussia became the main source of native Lithuanian literature and, in the 19th century, a haven for Lithuanians from russification. ${ }^{17}$

\footnotetext{
${ }^{15}$ The oldest preserved book in Latvian is a 1585 Catholic catechism of Petrus Canisius currently located at the Uppsala University Library. The first person to translate the Bible into Latvian was the German Lutheran pastor Johann Ernst Glück. Another German, Gotthard Friedrich Stender, was a founder of Latvian secular literature. He wrote the first illustrated Latvian alphabet book (1787) and the first encyclopedia, The Book of High Wisdom of the World and Nature.

${ }^{16} \mathrm{~A}$ study by two Hungarian sociologists contends that all the basic axial systems of belief are in retreat across Europe - especially in its main strongholds, often accompanied by generation conflicts. Thus, religiosity is lower among the younger generation everywhere than among the old, but especially in the still highly religious areas. Enlightenment ideology and rationality is mostly on the retreat today in France, its birthplace. The official socialist value system is collapsing in the former East Europe, while the social democratic value system is collapsing in Sweden. Finally, evident generation conflicts are present even in the value system of England, the home basis of Puritanism and also the working-class movement. See Arpád Skakolczai and László Füstös, "Value Systems in Axial Moments: A Comparative Analysis of 24 European Countries," European University Institute Working Paper SPS No. 96/8 (Florence, 1996). These conclusions are plausible but I find the value orientations ascribed to the Baltic republics and other countries unpersuasive and contradictory. Yes, devotion to Enlightenment rationalism is low in Russia and high in the Baltic. But it could not be higher in Lithuania than in Estonia, Latvia, and even Sweden. Yes, the ideology of social democracy may still be high in Sweden and Estonia, but not much lower than in Russia.

${ }^{17}$ V. Stanley Vardys and Judith B. Sedaitis, Lithuania: The Rebel Nation (Boulder, Co.: Westview, 1997), pp.
}

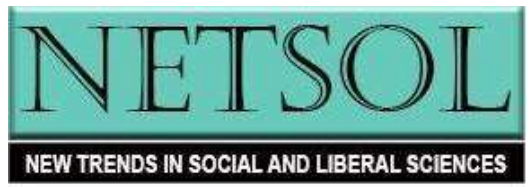


Max Weber argued that Protestantism conduced to the rise of capitalism. Protestants supplanted faith, hope, and charity - key virtues of Catholicism — with industry and thrift. Weber speculated that Calvinism changed Europe by its doctrine of predestination, which led some to hope that material prosperity in this life augured God's blessing. It is more likely that Lutherans contributed to economic development and to science by their belief that each individual should be able to read the Bible and interpret it for him/herself. ${ }^{18}$ Other world views, of course, can also spur a "Protestant" work ethic, as happened in Japan. ${ }^{19}$

The Reformation also led to decades of war between Protestant and Catholic regimes. After the 1648 Treaty of Westphalia, however, there emerged a new sort of live-and-let-live. Wars still happened but goaded by other issues. The Reformation gradually contributed to the growth of political as well as economic liberty and democracy. Protestant beliefs passed from German states and Sweden into the Baltic lands, especially Estonia and Latvia. They were transmitted by Protestant ministers, teachers, and university lecturers. Proximity to Europe meant that Balts could be shaped more by the Renaissance, the Reformation, the Enlightenment than most Russians. The upshot was that many Balts acquired world views much less mystical and less hierarchical than those promoted by Russian Orthodox Christianity. ${ }^{20}$

Some tsars and tsarinas sought to learn from Europe, only to revert to more authoritarian ways. The weight of tradition could not be overthrown by the occasional tutoring of some philosophe. Russians were taught to accept fatalistically the whims of authority. Their children were not schooled in Horatio Alger myths but in folk tales advising that wealth and happiness come by magic or by deceit. Hard work in these stories is seldom rewarded. Indeed, a brother and

\section{5-16.}

${ }^{18}$ Sweden's state church decreed in 1686 that everyone - including children, farm-hands, and maid-servantsshould "learn to read and see with their own eyes what God bids and commands in His Holy Word." Most Swedes learned to read within their own families, for there were few schools. By 1740 nearly all Swedes, male and female, could read (but not write) - almost 160 years before general literacy was achieved in England. Egil Johansson, "The history of literacy in Sweden," in Harvey J. Graff, ed., Literacy and Social Development in the West: A Reader (Cambridge: Cambridge University Press, 1981), pp. 151-82 at 157, 180. The UN Development Programme finds Sweden to be a world leader in gender equality.

${ }^{19}$ Thus, few Japanese or Chinese are Christian, but they find in their own cultures reasons to strive, save, invest, and plan for material success. Every "achieving society," David McClelland argued, socializes its children to believe that they should work, and that work will be rewarded. For a listing of relevant works by Max Weber, David McClelland and others, see Lawrence E. Harrison, Underdevelopment as a State of Mind (Lanham, MD: Madison, 1985).

${ }^{20}$ How all this happened-indeed, whether it happened - is debated. Did-could-provincial clergy and teachers make European intellectual and spiritual movements resonate for Baltic peasants and workers? If ideas determine political action, how is it that the epicenter of the Renaissance later gave birth to Mussolini? Of the Reformation, Hitler? Of the Enlightenment, Robespierre? See Jack F. Matlock, Jr., "The Poor Neighbor," New York Times Book Review, April 11, 1999, p. 11, review of Martin Malia, Russia Under Western Eyes: From the Bronze Horseman to the Lenin Mausoleum (Cambridge, Ma.: Harvard University Press, 1999).

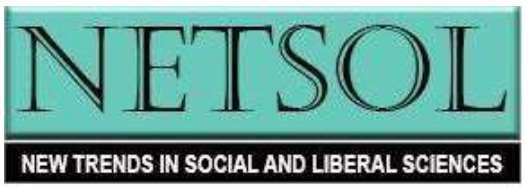


sister who go into the forest to gather wood for their aging parents' hearth are as likely to be zapped by Father Frost as to get home safely. ${ }^{21}$

Magic and deceit against the rulers are extolled in the fairy tales of other cultures. But "life itself" confirmed for Russians that hard work may not be rewarded. In Stalin's time, state terror often seemed random throughout the USSR. In Brezhnev's era, riches went to those with "connections." In the 1990s Kremlin cronies became overnight millionaires, while small businesses and savings could be wiped out by government fiat or ruble devaluations, as in August 1998. "Connections" still rule in the Putin era. Even billionaires had to fawn.

When Balts regained independence after decades of Soviet rule, it was not clear how much Protestant work ethic remained in the region. Many Balts no longer believed in any religion. But conditions in the 1990s showed Balts that hard work could earn wealth. The economic as well as the political outlooks of most Balts, including Lithuanians, was closer to views in Frankfurt or Geneva than to those prevailing in Moscow or Kyiv.

\section{Russia}

Did the Baltic miracle occur despite or thanks to proximity to Russia? In the second millennium Russia usually loomed as an imperial threat rather than as a partner in trade or defense. In 1242 the Grand Prince Alexander Nevsky defeated Teutonic Knights on Lake Peipsi between today's Estonia and Russia, but Russia seldom allied with Balts against invaders. Early in the $18^{\text {th }}$ century Peter the Great took what is now Estonia and Latvia from Sweden in a long war in which half to three-fourths of the local population died from fighting, hunger, and pestilence. In 1795 Russia also seized what is now Lithuania and parts of Poland. St. Petersburg ruled today's Baltic republics until its grip weakened in World War I.

In 1940 Soviet forces occupied and Moscow annexed the Baltic lands to shield the Soviet Union-not to protect Balts from Hitler. For two generations the USSR sought to russify and sovietize the Baltic countries. For better or worse, the Soviets did much to industrialize the region-especially Estonia and Latvia, and to promote Soviet-style education. But Balts led in some facets of education. Their middle schools ran one to three years longer than Soviet Russian schools. Post-Soviet Estonia became one of the most "wired" countries in the world (paralyzed at least once by Russian hackers). Some of its engineers became major innovators in Silicon Valley.

The greater the share of Russian residents, banks, mafias and other influences in Baltic life, the more corruption - as in Latvia, ranked $44^{\text {th }}$ out of 183 countries on the Corruption Perceptions Index of Transparency International. Estonia, by contrast, ranked $18^{\text {th }}$; Lithuania, $35^{\text {th }}$. Neighboring Poland ranked $41^{\text {st }}$ and Belarus $63^{\text {rd }}$. Ukraine and Russia, however, placed $126^{\text {th }}$ and $137^{\text {th }} .22$

\footnotetext{
${ }^{21}$ Walter C. Clemens, Jr., "Perestroika Needs a Work Ethic to Work," Wall Street Journal, December 5, 1989, op-ed.

${ }^{22}$ Transparency International, Corruption Perceptions Index 2019 at https://www.transparency.org/en/cpi/2019/results/ (accessed 10/11/20).
}

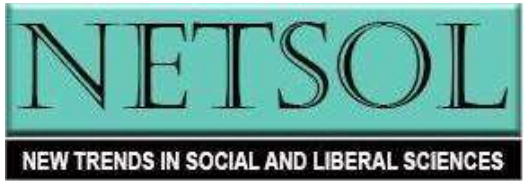




\section{Nationalism}

Did the Baltic miracle occur despite or thanks to nationalism? Until the 19th century, most humans identified with the village or land where they lived, hunted, or farmed - not with some abstract "nation," "state," or empire. ${ }^{23}$ No modern form of nationalism is much more than 500 years old. ${ }^{24}$ The Prussian-born scholar Johann Gottfried Herder in the late $18^{\text {th }}$ century taught that to live with meaning, every person must be part of a nation (Volk). ${ }^{25}$ Herder worked for five years in Riga and created an archive of Latvian folk songs. He wrote that every people has its own spirit (Volksgeist), expressed in its music and other traditions, worthy of respect. George Hegel added in the 1820s that every Volk needs its own state (Staat). "All worth that the human being possesses...he possesses only through the state." Herder's nationalism was pacifistic; Hegel's lent itself to violence. ${ }^{26}$

A spirit of nationalism can be based on a claim to shared blood lines-for example, "Aryan" descent. Such "ethnic" nationalism tends to "us versus them" intolerance. "Civic" nationalisms, by contrast, have sought to unite peoples on the basis of shared civic values. ${ }^{27}$ In the Baltic, as in Switzerland, elements of ethnic (more precisely, cultural) nationalism merged with civic sentiments. In Switzerland, German-speaking cantons joined with others that spoke French, Italian, or Romansch to form a confederation with a strong patriotic consciousness, one that also sought to override religious differences. ${ }^{28}$

${ }^{23}$ Italian nationalists derided "campanilismo" — the world view of persons whose perspective stopped at what they could see from the local bell tower [campanile].

${ }^{24}$ Liah Greenfeld, Nationalism: Five Roads to Modernity (Cambridge, Ma.: Harvard University Press, 1992). Two centuries before Henry VIII, however, English writers discussed an English "nation," while Chaucer in 1386 wrote about someone who, alas, had to travel to a "Barbre nacioun." For a catalog of national and ethnic stereotypes, see Shakespeare's Merchant of Venice (1596), where Portia scorns each type but also dislikes a man whose clothes and behavior are from "every where."

${ }^{25}$ League of Nations in German was Völkerbund; United Nations is Vereinte Nationen.

${ }^{26}$ On the views of Herder and Hegel and other thinkers on nationalism, see Walter C. Clemens, Jr., Dynamics of International Relations: Conflict and Mutual Gain in an Era of Global Interdependence, 2d ed. (Lanham, Md.: Rowman \& Littlefield, 2004), p. 275.

${ }^{27}$ The Indonesian ambassador to the Vatican described civic nationalism in his country: "In a diverse nation like Indonesia, ethnic diversity is given. Historically, the nation and state of Indonesia was built by consensus among people of different ethnicities, languages and religions. Nationalism in Indonesia is therefore classified as 'civic-nationalism'." He added: "Civic nationalism is conciliatory and forward-looking. This type of nationalism appeals to universal values, such as humanity, freedom and equality. Civic nationalism respects individual rights, tolerance and diversity. Those values fit well with the democracy that Indonesia embraces, but are incompatible with ethnic nationalism." A. Agus Sriyono, "Ethnic nationalism vs. civic nationalism," Jakarta Post, August 7, 2018.

${ }^{28}$ In 1982 I joined a mountain training course with a German-speaking unit of the Swiss Army from Zurich that was guided and instructed by two native French-speakers from Geneva. The unit's top officers, highly educated and accomplished in academia or business, were fluent in French and Italian as well as German and English.

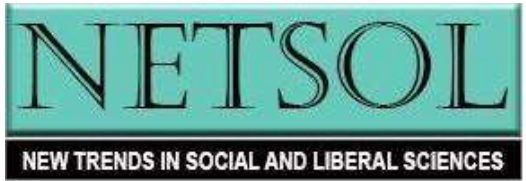


Ultimately, nationhood is a subjective reality. A nation is a group of people who believe or feel they constitute a nation, whether for "ethnic" or "civic" reasons. It is an imagined community, because most members can never know one another personally but choose to emphasize what unites them rather than what separates them. ${ }^{29} \mathrm{With}$ a population of just 922,000 native speakers, many Estonians could know or at least recognize one another as they walked along the harbor to the huge outdoor song festivals on a summer's night.

Nationalism is not identical to patriotism-devotion to one's fatherland (patrie in French).

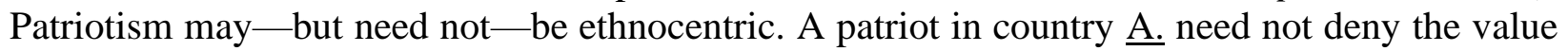
of country $\underline{B}$. Still, both patriotism and ethnocentrism can lead to fear of foreigners or xenophobia as well as to racism, chauvinism, and other aggressive forms of nationalism. ${ }^{30}$ Some nationalists feel that "we as a nation, have had a great past and, working together, will build a great future." Nationalism can be a secular religion - a belief that each person should feel a deep-perhaps supreme-loyalty to the nation. Nationalists usually look back as well as forward. If necessary, they invent a new past. For extreme nationalists, the nation is the tree, the individual a branch. The tree nourishes the branch but can live without it; the branch can be sacrificed for the tree. Many peoples believe they are "chosen" by God or Fate to do great things; some feel entitled to exploit the non-elect. This kind of nationalism never emerged in the Baltic.

Stalin saw nations as a fact that had to be integrated in a "socialist fatherland." He wrote: "A nation is a historically constituted, stable community of people, formed on the basis of a common language, territory, economic life, and psychological make-up manifested in a common culture." ${ }^{31}$ He named each union-republic for a nationality, such as Kazakh or Latvian, but tried to give diverse peoples a sense of civic unity. Stalin's ideas about nations developed when he stayed in Vienna, then heart of an empire that included many nations. But the Austro-Hungarian model collapsed in World War I, along with the Ottoman and Tsarist Russian empires. The Austrians and Turks tried to cultivate a sort of civic nationalism even as they permitted local cultures to practice their culture. These efforts ultimately failed as the subject peoples valued their own traditions and languages over those that prevailed in Vienna, Budapest, or Istanbul. Building on the former tsarist realm, the top-down Soviet "union" endured more than seven decades. When the central government wobbled, the union began to fall part. ${ }^{32}$

Estonians, Latvians, and Lithuanians wanted to freely use their own languages and enjoy music and other features of their cultures without foreign interference. The driving force behind Baltic nationalism has been cultural. In the Baltic, as in most of the world, nationalism emerged

\footnotetext{
${ }^{29}$ Benedict Anderson, Imagined Communities: Reflections on the Spread of Nationalism (Rev. ed.; London: Verso, 1991).

30"Chauvinism" derives from Nicholas Chauvin, a French soldier devoted to Napoleon.

${ }^{31}$ J. V. Stalin "Marxism and the National Question" (1913) in Joseph Stalin, Marxism and the National-Colonial Question (San Francisco: Proletarian Publishers, 1975), pp. 15-99 at 22.

${ }^{32}$ Apart from Korea and perhaps Japan (plus the many tribes or peoples without their own nation-states) few if any "nations" fit Stalin's criteria.
}

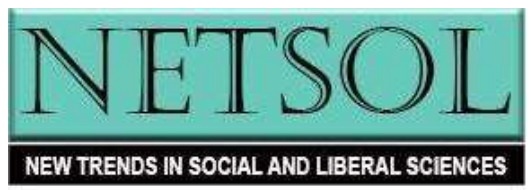


only in the 19th century. Most Balts then were still peasants, but modernization buttressed nationalism. The introduction of railroads permitted church choirs from scattered parishes to come together for festivals of traditional music. People met, recalled, celebrated, and strengthened their common heritage. Tsarist Russian and later Soviet officials tried to throttle Baltic nationalisms, but Balts persisted with music festivals that affirmed their national identities. Their drive for independence in the 1980s became a "Singing Revolution." ${ }^{33}$ As one participant put it, "Somehow we sang ourselves free from Soviet repression, both personally and politically." ${ }^{34}$ Music sustained Balts, as it did repressed Irish and Jewish people. ${ }^{35}$

Having lived on the amber coast for millennia, Estonians, Latvians, and Lithuanians became deeply attached to their territories as well as to their languages and cultures. A national spirit in each republic was fostered by a shared mythology, shared religious texts (especially those printed in the vernacular), and-over time-by a communications infrastructure. Alien rule spurred Baltic nationalisms in the 19th and 20th centuries and was kept alive in the $21^{\text {st }}$ by Russian threats. For Balts, nationalism offered a way to counter political repression. Balts in the late Soviet years feared that their genes and cultures could disappear unless they drove out alien controls. They also feared that Soviet practices would damage their environment, for example, by the phosphorite mines in Estonia. Throttled by Russian tsars but encouraged by Woodrow Wilson, local nationalisms fueled the creation of the three Baltic republics in the 1920s. Put down again by Soviet commissars but given some leeway by the Gorbachev Kremlin, Baltic nationalisms reemerged in the 1980s.

Many "native" Estonians and Latvians had German or Russian roots, manifest in their family names. But the numbers of settlers who could not speak a Baltic language greatly increased under Soviet rule. In the 1980s at least half the residents of Latvia were Slavic speakers; in Estonia, two-fifths; in Lithuania, one-fifth. Naturally, Russian became a lingua franca, with street signs in two languages - with many streets named for Soviet heroes, such as Yuri Gagarin. Locals complained that settlers from Russia got the best apartments and jobs. The number two in Communist Party ranks was usually a Russian. My own entry into Baltic studies was triggered in the 1988 glasnost' era by articles complaining about Russian bullying in the Russia language newspaper Sovetskaia Estoniia. ${ }^{36}$

\footnotetext{
${ }^{33}$ Clemens, Baltic Independence and Russian Empire.

${ }^{34}$ Interview and analysis in Steven J. Pierson, "We Sang Ourselves Free: Musical Experience and Development among Christian Estonians from Repression to Independence," paper presented at Södertorn Högskola, Sweden, in July 1999. For the full story, Guntis Šmidchens, The Power of Song: Nonviolent National Culture in the Baltic Singing Revolution (Seattle: University of Washington Press, 2014).

${ }^{35}$ Pierson, "We Sang Ourselves Free." Songs written in camps and ghettoes sustained Jewish prisoners reminding them of life - not death. Gila Flam, Singing for Survival: Songs of the Lodz Ghetto, 1940-45 (Urbana: University of Illinois Press, 1992). Hong Kong protestors against Chinese domination sang together in 2019 and again in 2020.

${ }^{36}$ Walter C. Clemens, Jr., "Estonia, A Place to Watch,” The National Interest (Fall 1988) 13: 85-92.
}

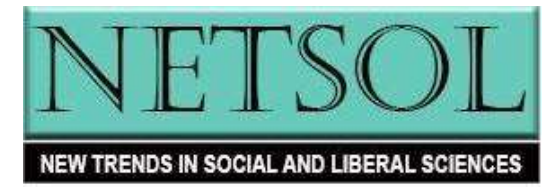


How to preserve Baltic cultural traditions and accommodate all those who did not share those customs or even despised them? In December 1991, the Lithuanian legislature voted to grant citizenship to all residents who applied for it, took a loyalty oath, and showed proof of having renounced any other citizenship. The 1991 law was amended in 1995 to provide citizenship to persons born within the borders of the republic who themselves, or whose ancestors, were citizens of Lithuania before 1940, or who became citizens under previous legal authority. In the 1990s more than 90 percent of the country's Slavic speaking inhabitants received citizenship. For persons not qualifying under these categories, naturalization required a ten-year residency, a permanent job or source of income, knowledge of the constitution, renunciation of any other citizenship, and proficiency in Lithuanian. The independence leader Vytautas Landsbergis told me in 1996 that every citizen "must feel in favor of the country." He endorsed integration-not assimilation. He and his followers backed laws that supported schools in the language of every minority. In the late 1990s nearly 15 percent of Lithuanian schoolchildren received their education in a minority language such as Polish, Russian, Yiddish, and Belarusian. Slavic speakers presented little threat to Lithuania, but Russia continued pressure from outside by manipulating the oil spigot, exploiting waters claimed by both sides, by military maneuvers, and coordinated actions with Belarus.

Intent on restoring a nation-state and fearful their cultures could disappear in a Slavic sea, Estonia and Latvia in 1991-1992 granted citizenship automatically on the basis of "descent." For others, citizenship required naturalization. When Estonia in 1992 reintroduced the Citizenship Act of 1938, about one third of its population became stateless. The 1992 law was based on the idea of the "legal continuity" of the pre-war Estonian Republic. Thus, only those persons who were citizens before Estonia's incorporation into the Soviet Union in 1940 and their descendants were entitled to automatic citizenship. Migrants to Estonia from the Soviet period and their descendants, by contrast, had to go through the process of naturalization to obtain Estonian citizenship.

Estonia and Latvia established procedures for naturalization that required several years of residency, some knowledge of the local language and constitution, a legal source of income, and a loyalty oath. Certain classes of persons were not eligible such as criminals, former intelligence agents and career soldiers of a foreign state. But the social rights enjoyed by stateless persons differed little from those of Estonian citizens. Only citizens, however, could vote and run in the parliamentary elections or for certain public positions regarded as important for the public interest. As a result, many Russian speakers chose to adopt Russian citizenship or remain stateless noncitizens in Estonia.

In the 1990s these rules were watered down, and deadlines extended. Political parties representing minority interests took part in elections and won seats in national governments as well as local councils. Noncitizens were free to do business and make money. Non-citizens received the same government pensions as citizens. Most outside observers felt that no Baltic country violated the human rights of its residents. Russia, however, passed "compatriot" laws authorizing the government to defend the rights of Russians born or living elsewhere-presumably

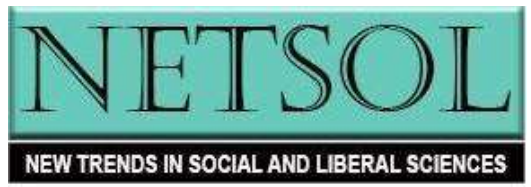


even in Alaska. ${ }^{37}$ When I talked with young Russian-speakers in Estonia and Latvia in 1999, however, these issues were not salient for them. Even in Narva, across the river from Ivangorod, few young people had visited Russia or showed much desire to do so. Young people in each Baltic republic learned the local language as a matter of course, even if they attended Russian-language schools. Older people experienced more difficulty or did not try.

Nations and national consciousness are not "primordial"— not inherent in genes, territory, or even language. History makes and constantly remakes what we call "race," "nation," "culture," and "language." No person has "Estonian," "Latvian," or "Lithuanian" stamped into her or his genes. Of course, foreign influences have been weighty and may become even weightier. Still, how Balts live in the 21st century derives from an ancient peasant ethos. The peasant socioeconomic unit common in the Baltic lands nurtured the seeds of a democratic culture. While Russian peasants lived in communes before and after the elimination of serfdom, farming in the Baltic lands was based on family farms conducive to an individualistic consciousness that, when foreign domination collapsed, eased the transition to a democratic political economy.

In today's Estonia the cooperative peasant ethos had blended with the technological acumen of one of the world's most wired countries to develop "e-democracy." The Estonian Cooperation Assembly curates a People's Initiative website that has become a convenient and transparent digital channel between citizens and the legislature in recent years. ${ }^{38}$ The success of edemocracy has increased people's participation in government affairs, even between elections. It has also honed collective skills for making proposals. The Cooperation Assembly also conducts a traveling exhibition called "Compass of the Homeland" that encourages citizens to evaluate conditions in their hometowns and to have a say in environmental issues. The Compass seeks to promote brainstorming, space experiments, and discussion on the creation of better living situations. It seeks cooperation between the local government and the community to create a stronger sense of ownership and collective care. The strategic topics emphasized by the Cooperation Assembly stem from Estonian Human Development Reports (EHDR), compiled by social scientists from the Estonian Cooperation Council, a thinktank, and published by the Cooperation Assembly every second year. In 2020 the Council is debating what topic to emphasize in the next EHDR.

Despite the intermingling of natives and Slavs in the Baltic, ethnic hostilities have never provoked serious violence. Looking into the 21st century, how will the nationalisms of Estonians, Latvians, and Lithuanians - again housed in independent states - coexist with the sentiments of Slavic-speakers in their midst? Will Baltic natives and Slavic settlers feel as one in a unified country or remain distant from one another-perhaps like Walloons and Flemings in Belgium or

\footnotetext{
${ }^{37}$ Clemens, Baltic Transformed, pp. 113, 182-85, 196-97.

${ }^{38}$ The Cooperation Assembly [Eesti Koostö̈ Kogu] was founded in 2007 by the President of Estonia. It works on policy recommendations and initiatives on societal issues such as e-democracy and public sector reform. The Council has eight members - four assigned by Estonia's president and four chosen by the collaboration network. For its strategy, activities, and reports, see https://www.kogu.ee/en/activity/ (accessed 9/30/20).
}

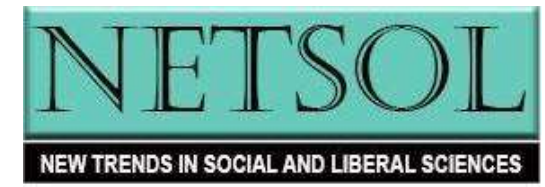


Jews and Arabs in Israel? And how will local ties mesh with global? How will Baltic natives and Slavic settlers interact with the transnational forces arising from a uniting Europe and a U.S.dominated global culture? Will their offspring utilize one, two, three, or more languages? Will it be a Baltic or Slavic tongue in one context-English, German, or Chinese in others? What will be the impact of cross-border global influences? One might hope for a Swedish model, manifest in the way teenager Greta Thunberg could address Davos and the United Nations in elegant English.

\section{Interdependence}

Did the Baltic miracle take place thanks to or despite interdependence? Interdependence is more than interconnectedness. It is a relationship in which the well-being of two or more actors is vulnerable (as in mutual deterrence) or at least sensitive, to changes in the condition or policies of the other. ${ }^{39}$ It means mutual dependence - a domain between the extremes of absolute dependency and complete interdependence. Though interdependence may lead to mutual benefit, interdependent actors are linked so closely that a change in the conditions or policies of one actor will impact the other in ways that it cannot easily change. No matter how many soldiers they train, the Baltic states will probably remain vulnerable to a Russian invasion, while Russia can never be threatened by Balts unless pushed by other NATO powers. ${ }^{40}$ Balts were thought in the 1990 s to be deeply vulnerable to Russian oil blockades, but they turned out to be merely sensitive. Indeed, Russian suppliers of oil and Baltic refiners and shippers turned out to need each other.

Balts have long been sensitive if not vulnerable to one another, to their immediate neighbors, and to others near and far-from Novgorod and Byzantium to London. Their mutual dependence has existed for many centuries and spanned many realms-economics, security, culture, environmental protection. But the Industrial Revolution and modern communications weakened national boundaries and strengthened global interdependence. ${ }^{41}$ Interdependence by itself is neither good nor bad. It is a fact. How humans deal with this condition generates gain or pain. Some actors and analysts perceive certain interdependencies to be zero-sum, negative-sum, or positive-sum, but the realities of world affairs are generally variable-sum, with a potential—as

\footnotetext{
${ }^{39}$ The argument here follows Robert O. Keohane and Joseph S. Nye, Power and Interdependence (2d ed.; New York: HarperCollins, 1989) In chapter one, Kenneth Waltz, however, argued that to accept interdependence as mere sensitivity, guts the term of any political meaning.

${ }^{40}$ Lithuania is less vulnerable because it borders Russia only at Kaliningrad. However, it also borders Belarusat times, a virtual Russian ally.

${ }^{41}$ As Karl Marx and Friedrich Engels put it in the 1848 Communist Manifesto: "The bourgeoisie [capitalist class] has through its exploitation of the world-market given a cosmopolitan character to production and consumption in every country....It has drawn from under the feet of industry the national ground on which it stood. All old-established national industries have been destroyed....They are dislodged by...industries that no longer work up indigenous raw material, but raw material drawn from the remotest zones; industries whose products are consumed, not only at home, but in every quarter of the globe. In place of the old wants, satisfied by the productions of the country, we find new wants, requiring for their satisfaction the products of distant lands and climes. In place of the old local and national seclusion and self-sufficiency, we have intercourse in every direction, universal interdependence of nations" [allseitige Abhängikeit].
}

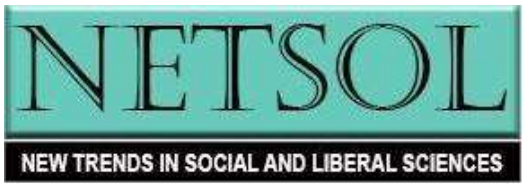


in the game of Prisoner's Dilemma - to beggar one's neighbor or, alternatively, to optimize common interests. Many societies decline when their members fail to pool their strengths for the common good. ${ }^{42}$

Is interdependence growing? Experts disagree on the extent of interdependence and what it means for world politics. But the overall picture seems to be one of escalating interdependenceon many issues and among many partners-worldwide. The Kremlin long denied the Soviet Union's shared dependencies with the outside world and sought self-sufficiency. But in the 1970s Soviet spokesmen reluctantly acknowledged "global problems too complex to be resolved by any single country." In the 1980s Soviet Communist Party General Secretary Mikhail Gorbachev explained that the world is "contradictory but also integral and interdependent."43 In the 1990s Balts reduced linkages with Russia and worked to cultivate a deep and multifaceted interdependence with the rest of Europe. Each of the approaches reviewed here helps to understand Baltic exceptionalism. For a fuller picture, let us consider the principles laid out in complexity science.

\section{Complexity Science}

Like Social Darwinists, ultra-realists in international affairs teach that might equates to right: survival in world politics, as in the jungle, depends upon strength and rugged individualism. Against this view, some students of complexity science and other scholars argue that survival and prosperity depend not just on individual strength but on a capacity for self-organization to promote mutual gain. ${ }^{44}$ Complexity science thus enlarges the insights of Petr Kropotkin at the turn of the 19th century. He too studied the evolution of all life forms. Long before complexity science emerged, Kropotkin denied that rugged individualism is the sole key to survival. Cooperationwhether spontaneous or deliberate, he argued, can promote survival. ${ }^{45}$

\footnotetext{
${ }^{42}$ Interdependence offers a paradigm for a grand theory superior to political realism or idealism. Viewing the world as interdependent encourages long-term calculations and enlightened self-interest rather than myopic Realpolitik or naive utopianism. The lens of interdependence discourages self-righteousness and encourages efforts to understand the values of each party. Interdependence does not suffice to make one from many. Most Canadians and U.S. citizens may see themselves and their countries as interdependent - Canadians and "Americans" trade more with each other than with any other country. Still, they do not see themselves as a single political community. Similarly, even though many Estonians, Latvians, and Lithuanians may see themselves as interdependent, their mutual vulnerability does not convert to a common nationality.

${ }^{43}$ In the 1960s and 1970s the U.S. State Department asserted the "interdependence" of the Western allies and called for closer ties between them and less developed countries. Soviet spokesmen countered that American talk of interdependence masked U.S. ambitions to dominate the world. See Walter C. Clemens, Jr., Can Russia Change? The USSR Confronts Global Interdependence (New York: Routledge, 1990 and 2004).

${ }^{44}$ For a critique of neorealists' emphasis on the structure of power in world affairs, see Jack Snyder and Robert Jervis, eds., Coping with Complexity in the International System (Boulder, Co.: Westview, 1993).

${ }^{45}$ Kropotkin's book Mutual Aid (1902) sought to rebut Thomas H. Hassle, "The Struggle for Existence" (1888). Both works are republished in Kropotkin, Mutual Aid: A Factor of Evolution (Boston: Extending Horizons, 1955); also Kropotkin, Ethics, Origin and Development (New York: Dial Press, 1924).
}

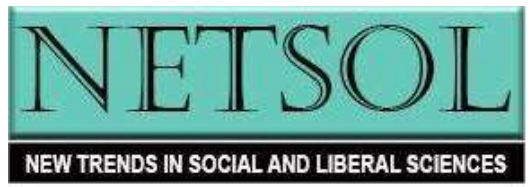


Developed by scholars from various disciplines, complexity science integrates concepts from many fields to produce a new slant on evolution. ${ }^{46}$ Its ambition is suggested by the subtitle of a book by a leading complexity scholar, Geoffrey West, Scale: The Universal Laws of Growth, Innovation, Sustainability, and the Pace of Life in Organisms, Cities, Economics, and Companies. ${ }^{47}$ If this ambition succeeds, complexity science should also help us to understand development and security issues in the Baltic region. ${ }^{48}$ Whatever its limitations, complexity science can enlarge our vision and complement other approaches to analysis of world affairs. ${ }^{49}$ How this could develop in international studies is suggested by various scholars in World Politics at the Edge of Chaos: Reflections on Complexity and Global Life edited by Emilian Kavalski and in my Complexity Science and World Affairs. ${ }^{50}$

${ }^{46}$ The following interpretation of complexity science is based primarily on the work of Stuart Kauffman and other scholars - from Nobel physics laureate Murray Gell-Mann to Nobel economics laureate Kenneth Arrow-who have interacted at the Santa Fe Institute. For a summary of their early efforts, see Roger Lewin, Complexity: Life at the Edge of Chaos (New York: Macmillan, 1992). Stuart Kauffman's major works include The Origins of Order: Self-Organization and Selection in Evolution (New York: Oxford University Press, 1993) and At Home in the Universe: The Search for Laws of Self-Organization and Complexity (New York: Oxford University Press, 1995). The Santa Fe Institute, founded in 1984, publishes the journal Complexity. For a skeptical view of complexity theory, see John Horgan, The End of Science: Facing the Limits of Knowledge in the Twilight of the Scientific Age (Reading, Mass.: Addison-Wesley, 1996), chaps. 5-9. For a more balanced appraisal, see the "Edge of Chaos" and many relevant entries in Ian Marshall and Danah Zohar, Who's Afraid of Schrödinger's Cat: All the Science Ideas You Need to Keep Up with the New Thinking (New York: Morrow, 1997).

${ }^{47}$ See Robert M. Axelrod, The Complexity of Cooperation: Agent-Based Models of Competition and Cooperation (Princeton: Princeton University Press, 1997) and the work of his student, Lars-Erik Cederman, Emergent Actors in World Politics: How States and Nations Develop and Dissolve (Princeton: Princeton University Press, 1997). Compare with James N. Rosenau, Turbulence in World Politics: A Theory of Change and Continuity (Princeton: Princeton University Press, 1990).

${ }^{48}$ Geoffrey West, Scale: The Universal Laws of Growth, Innovation, Sustainability, and the Pace of Life in Organisms, Cities, Economics, and Companies (New York: Penguin, 2017). Reasons for optimism and pessimism may be found in Walter C. Clemens, Jr. and Stuart A. Kauffman, "Is the World Chaos, a Machine, or Evolving Complexity? How Well Can We Understand Life and World Affairs?" NETSOL, 4/2, (Fall 2019): 24-43. For background, see "Evolutionary Paradigms in the Social Sciences," Special Issue, International Studies Quarterly 40, 3 (September 1996); for applications and an extensive bibliography, Joshua M. Epstein and Robert Axtell, Growing Artificial Societies: Social Science from the Bottom Up (Cambridge: The MIT Press, 1996).

${ }^{49}$ See the call for a "jumping together" of ethics, life sciences, social sciences, and aesthetics in Edward O. Wilson, Consilience: The Unity of Knowledge (New York: Knopf, 1998); also Hayward Alker, Rediscoveries and Reformulations: Humanistic Methodologies for International Studies (Cambridge: Cambridge University Press, 1996).

${ }^{50}$ Emilian Kavalski, ed., World Politics at the Edge of Chaos: Reflections on Complexity and Global Life (Albany: State University of New York Press, 2015); Clemens, Complexity Science and World Affairs (Albany:

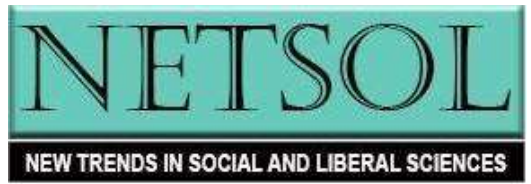


How does complexity science help to explain Baltic development? This approach to knowledge is anchored in nine basic concepts: nonlinear development, fitness, coevolution, selforganization, emergence, agent-based systems, self-organized criticality, punctuated equilibrium, and fitness landscapes. ${ }^{51}$ These concepts are summarized in Table 1, but the relevance of selforganization to Baltic development is highlighted here. Balts manifested a capacity for selforganization in the late 1980s as they formed popular fronts of non-Communists and Communists to advance their goals within the framework of perestroika (structuring), glasnost (openness), and a law-based society as championed by Soviet leader Gorbachev. Perestroika - restructuringmeant they could initiate businesses not controlled by the state; glasnost' - openness - meant more freedom to speak and write openly; law-based society meant actualizing the rights already provided in Soviet law such as the right of every republic to self-determination.

Self-organization was evident in the huge music and dance festivals organized in each Baltic republic - now using traditional songs instead of paeons to the Soviet fatherland. The popular fronts that took shape in each Baltic republic cooperated with each other, for example, organizing the "Baltic way." This was a peaceful political demonstration by some two million people who joined their hands forming a 600-kilometer long human chain through the Baltic countries to demonstrate their unity in their efforts towards freedom. The event took place on August 23, 1989-fiftieth anniversary of the Molotov-Ribbentrop secret protocols that authorized the Soviet take-over that occurred in 1940.

People in the other Soviet republics could also have exploited the Gorbachev reforms and some tried to do so. Kazakh poet Olzhas Suleimenov, for example, inspired Soviet and foreign medical experts to organize the Nevada-Semipalatinsk conference in 1990 that sought a global ban on underground nuclear tests like the one that had recently vented in Kazakhstan. ${ }^{52}$ Dissidents in Ukraine and some other Soviet republics had protested Soviet dictatorship for years and some stepped up their activities in the late 1980s. But none managed, as in the Baltic, to unite and mobilize a strong majority of the local population and to do so within the loosening framework of Soviet law and enforcement.

State University of New York Press, 2013).

${ }^{51}$ My book speaks of "science" rather than "theory" because scholars in the field seek "science" but do not agree on a particular "theory." For a Russian's perspective, see Historical Dynamics and Development of Complex Societies, eds. Andrey Korotayev et al. (Moscow: URSS Editorial, 2006).

${ }^{52}$ On Olzhas Suleimenov, see Clemens, "Can a Poet Stop Nuclear Testing?" Christian Science Monitor, December 26, 1990. In the spirit of glasnost', a Kazakh newspaper reprinted my "Russia Should Let Its' People Go," Christian Science Monitor, May 25, 1990, translated and critiqued in Karagandiskii Universitet.

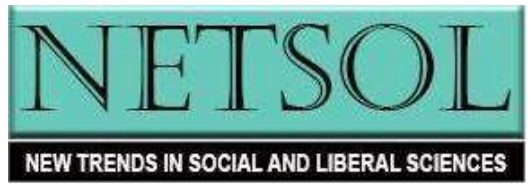




\section{Table 1: Basic Concepts of Complexity Science}

Nonlinear development: Nonlinearity and complexity are hallmarks of social networks. Complexity science endeavors to explain the process of complex adaptation within complex systems - whether they be ecosystems, the Internet, or political systems.

Fitness: Complexity science defines fitness as the ability to cope with complexity; to process information about and deal with many variables; survive challenges and make the most of opportunity.

Fitness also requires a capacity to defend against external threats and, in a world where peace is indivisible, contribute to collective action against aggressors and violators of human rights. The fitness of regional and global systems can be measured by their ability to foster peace, economic well-being, justice, liberty, environmental quality, cultural and spiritual development.

A fit human society has the means to cope with complex challenges and opportunities at home and abroad. Fitness requires both order and freedom, but a fit society avoids the Scylla of rigid hierarchy and Charybdis of social chaos. All life forms exist on a spectrum ranging from instability (chaos) to ultra stability (ordered hierarchy). Fitness is found between rigid order and chaos - not in a crystal, where every atom resides in an ordered hierarchy; nor in gases whose molecules move at random. Some complexity experts say that fitness is found at the "edge of chaos." It is more accurate to think of fitness as located at the top of a bell-shaped curve leading toward chaos and rigid order. Move too far toward either pole, and you lose fitness.

Coevolution: No organism evolves alone. Every individual, species, and society coevolve with others and with their shared environment. A change in any one actor or environment can alter the fitness of multiple actors. This is the "butterfly effect" of chaos theory, which underscores the difficulty in understanding complex interactions. The more variables shape a system, the harder to anticipate how change in one element will affect others. Complexity science, however, aspires to identify patterns and even, as Geoffrey West's ambition suggests, universal laws.

Self-organization: Complexity science modifies Darwin's emphasis on natural selection as the key to evolution. Survival in coevolution is determined not just by luck (the correspondence between genetic mutations and environmental conditions), but by a capacity for self-organization. A fit society self-organizes to help its members choose how to fulfill their human potential.

Emergence: Coevolution often gives rise to "emergent properties"- holistic phenomena richer than the sum of their parts - even their genes and chemical ingredients. Thus, an infant's brain can learn more rules than are contained in its genes. Coevolution often manifests "order for free." This could but need not imply a Creator or grand Watchmaker.

Agent-based systems: An agent-based system is one in which independent actors, each following a few rules, self-organize to form an emergent phenomenon without central direction from above. Thus, many species interlock in a coral reef and provide one another protection from predators,

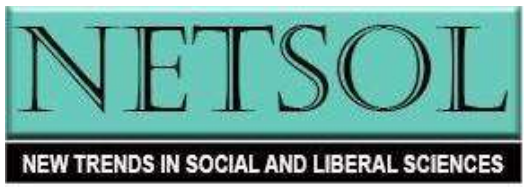


temperature extremes, and strong currents. Without planning, they cooperate for mutual gain. Like a coral reef, every durable ecosystem is an emergent phenomenon. The system offers protection against the ravages of storms and alien species, but it is fragile. A coral reef, for example, can be broken by severe storms or killed by temperature change. But many ecosystems endure for long periods.

Self-organized criticality: Balanced between order and chaos, a fit being is like a sandpile which, if one more grain of sand is added, may collapse in an avalanche. This fragile equilibrium is called self-organized criticality. The sandpile metaphor, however, is not universally accepted. Also, scientists in many fields have noticed that critical events occur more often - both earlier and later than forecast - in a bell-shaped curve.

Punctuated equilibrium: Complexity science adopts the concept of punctuated equilibrium from paleontology. It underscores that evolution is often marked by surges of speciation and avalanches of extinction. Species often develop quickly, endure with little change for a long time, and then die out suddenly - not gradually. Thanks to mutation and self-organization, members of the species find their niche and hang on to it. When their environment changes, they must adapt or disappear. The complexity science notion of fitness helps account for punctuated equilibrium. The rise, long ascendancy, and decline of the Hanseatic city-states on the Baltic coast fits the pattern of punctuated equilibrium.

Fitness landscapes: Complexity science suggests that coevolution can be mapped as a rugged landscape in which each actor's fitness appears as a peak. The relative and changing fitness of each organism is shown as a peak rising or falling as a consequence of coevolution. As in an arms race, the peaks of a predator and its prey may gain or decline according to changes in their offensive and defensive capabilities. If attackers increase their speed or acquire more lethal weapons, the fitness peak of the prey will drop. If individuals among the prey population acquire characteristics that reduce their vulnerability, their peak will rise.

\section{How Do the Parts Intertwine?}

We have seen that the three Baltic republics emerged from Soviet rule with little violence and soon integrated smoothly with the West including the European Union and NATO. Rising levels of societal fitness in the Baltic states were reflected in their rising scores on the UN Human Development Index. However economic gains as well as continuing shortfalls contributed to steep population declines, 1990 to 2020. The Baltic transformation at the end of the 20th century departed sharply from a long history in which Balts lived more as objects - passive victims - than as agents of their own destiny. History, of course, did not end. ${ }^{53}$ The transition of Estonia, Latvia, and Lithuania to functioning members of the "First World" was not perfect. The new politics did not elicit strong participation by young people; the new societies did not rush to integrate ethnic

\footnotetext{
${ }^{53}$ For a rebuttal to endism, see David Gress, From Plato to NATO: The Idea of the West and Its Opponents (New York: Free Press, 1998).
}

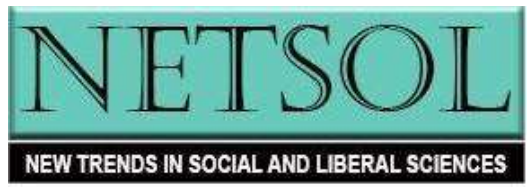


minorities; the new economics did little to cushion the transitional costs for the poor and the elderly. In each republic some people yearned for the good old days when Big Brother provided a low-level welfare state.

Was the glass half empty or half full? Baltic performance since 1991 has been quite good relative to resources and the enormous tasks at hand. Not only did Balts score many near-term achievements, but they also laid the foundations for gradual amelioration of underlying problems. Many problems would take time to ameliorate. If the new economics succeeded, the next generations of elderly may be able to retire with greater confidence in their material assets. Their own savings and pensions would rest on stronger foundations than in the 1990s.

These achievements have emerged despite a dark history - many centuries of top-down controls by German, Swedish, and Russian imperialists, with a twenty-year interregnum of selfrule followed by a few years of Nazi occupation and fifty years of Soviet oppression. A millennium of darkness was brightened in the $17^{\text {th }}$ and $18^{\text {th }}$ centuries by Swedish and German Protestants who introduced mass literacy and some respect for individual dignity along with kernels of free thought. These three revolutionary changes were crucial in developing a capacity for self-organization, which complexity science sees as key to societal fitness. The other former Soviet republics support mass literacy but most (except for the people of Ukraine and Belarus) still lack respect for individual dignity and free expression. This situation also contains lessons for the top-down regimes across Asia, the Middle East, and developing countries from Cuba to Ethiopia. To raise human development, they must first cultivate self-organization - the antithesis of authoritarian rule.

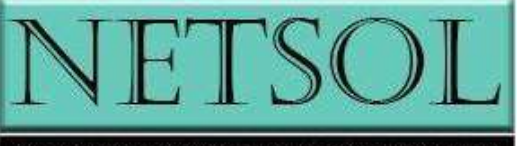




\section{Bibliography}

Alker, Hayward R. Rediscoveries and Reformulations: Humanistic Methodologies for International Studies. Cambridge: Cambridge University Press, 1996.

American Heritage Dictionary of the English Language. 3d ed.; Boston: Houghton-Mifflin, 1992.

Anderson, Benedict. Imagined Communities: Reflections on the Spread of Nationalism. Rev. ed.; London: Verso, 1991.

Åslund, Anders. "The Baltic Tigers: Past, Present and Future Why Have the Baltic Tigers Been So Successful?" CESifo Forum 4/2015 (December) at https://www.ifo.de/DocDL/forum2015-4-aslund-baltic-tiger-december.pdf.

Axelrod, Robert M. The Complexity of Cooperation: Agent-Based Models of Competition and Cooperation. Princeton, N.J.: Princeton University Press, 1997.

Cederman, Lars-Erik. Emergent Actors in World Politics: How States and Nations Develop and Dissolve. Princeton, N.J.: Princeton University Press, 1997.

Clemens, Walter C., Jr. Baltic Independence and Russian Empire. New York: St. Martin's, 1991.

. The Baltic Transformed: Complexity Theory and European Security. Lanham, MD: Rowman \& Littlefield, 2001.

. "Can a Poet Stop Nuclear Testing?" Christian Science Monitor, December 26, 1990.

- Can Russia Change? The USSR Confronts Global Interdependence. New York: Routledge, 1990, 2004.

. Complexity Science and World Affairs. Albany: State University of New York Press, 2013.

. Dynamics of International Relations: Conflict and Mutual Gain in an Era of Global Interdependence, 2d ed. Lanham, Md.: Rowman \& Littlefield, 2004.

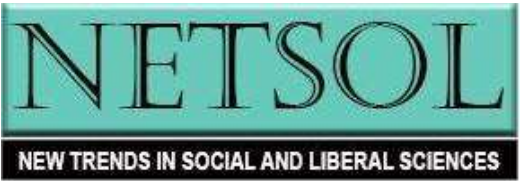


. "Ecology and International Relations," International Journal (Winter 1972-73) 28, 1: 127.

. "Estonia, A Place to Watch," The National Interest (Fall 1988) 13: 85-92.

. "Perestroika Needs a Work Ethic to Work," Wall Street Journal, December 5, 1989.

. "Russia Should Let 'Its' People Go," Christian Science Monitor, May 25, 1990.

Clemens, Walter C., Jr. and Stuart A. Kauffman, "Is the World Chaos, a Machine, or Evolving Complexity? How Well Can We Understand Life and World Affairs?" NETSOL, 4/2, (Fall 2019): 24-43.

Epstein Joshua M. and Robert Axtell. Growing Artificial Societies: Social Science from the Bottom Up. Cambridge: The MIT Press, 1996.

Flam, Gila. Singing for Survival: Songs of the Lodz Ghetto, 1940-45. Urbana: University of Illinois Press, 1992.

Gould, Stephen Jay. Wonderful Life: The Burgess Shale and Nature of History. New York: W. W. Norton, 1989.

Greenfeld, Liah. Nationalism: Five Roads to Modernity. Cambridge: Harvard University Press, 1992.

Gress, David, From Plato to NATO: The Idea of the West and Its Opponents. New York: Free Press, 1998.

Gumenyuk, Ivan. "Human Development Index as a Tool to Assess Social Development in the Baltic States," Baltic Region (October 2017) 9, 3: 45-57.

Harrison, Lawrence E. Underdevelopment as a State of Mind. Lanham, MD: Madison, 1985.

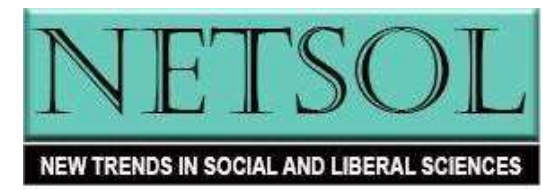


Hoffmann, Matthew J. "Constructivism and Complexity Science: Theoretical Links and Empirical Justification," presented at Annual Meeting, International Studies Association, Washington, D.C., February 16-21, 1999.

Hough, Jerry F. Democratization and Revolution in the USSR, 1985-1991. Washington, D.C.: Brookings Institution Press, 1997.

Johansson, Egil. "The history of literacy in Sweden," pp. 151-82 in Harvey J. Graff, ed., Literacy and Social Development in the West: A Reader. Cambridge: Cambridge University Press, 1981.

Kauffman, Stewart A. At Home in the Universe: The Search for Laws of Self-Organization and Complexity. New York: Oxford University Press, 1995.

. The Origins of Order: Self-Organization and Selection in Evolution (New York: Oxford University Press, 1993).

Kavalski, Emilian, ed. World Politics at the Edge of Chaos: Reflections on Complexity and Global Life. Albany: State University of New York Press, 2015.

Keohane, Robert O. and Joseph S. Nye. Power and Interdependence,2d ed. New York: HarperCollins, 1989.

Korotayev, Andrey et al., eds. Historical Dynamics and Development of Complex Societies. Moscow: URSS Editorial, 2006.

Kropotkin, Petr. Ethics, Origin and Development. New York: Dial Press, 1924. . Mutual Aid: A Factor of Evolution. Boston: Extending Horizons, 1955.

Lewin, Roger. Complexity: Life at the Edge of Chaos. New York: Macmillan, 1992.

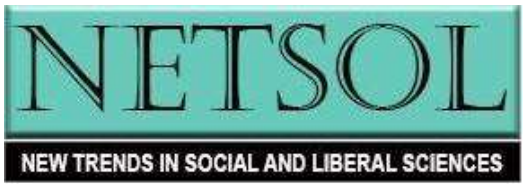


Lipson, Michael. "Nonlinearity, Constructivism, and International Relations: Or, Changing the Rules by Playing the Game," presented at Annual Meeting, American Political Science Association, Chicago, August 31-September 3, 1996.

Lumsden, Charles J. and Edward O. Wilson. Genes, Mind, and Culture: the Coevolutionary Process. Cambridge: Harvard University Press, 1981.

Marshall, Ian and Danah Zohar. Who's Afraid of Schrödinger's Cat: All the Science Ideas You Need to Keep Up with the New Thinking. New York: Morrow, 1997.

Marx, Karl and Friedrich Engels. Communist Manifesto, 1848 with many subsequent revisions.

Matlock, Jack F. Jr. "The Poor Neighbor," New York Times Book Review, April 11, 1999.

Pierson, Steven J. "We Sang Ourselves Free: Musical Experience and Development among Christian Estonians from Repression to Independence," paper presented at Södertorn Högskola, Sweden, in July 1999.

Rosenau, James N. Turbulence in World Politics: A Theory of Change and Continuity. Princeton, N.J.: Princeton University Press, 1990.

Skakolczai, Arpád and László Füstös. "Value Systems in Axial Moments: A Comparative Analysis of 24 European Countries,” European University Institute Working Paper SPS No. 96/8, Florence, 1996.

Šmidchens, Guntis. The Power of Song: Nonviolent National Culture in the Baltic Singing Revolution. Seattle: University of Washington Press, 2014.

Snyder, Jack and Robert Jervis, eds., Coping with Complexity in the International System. Boulder, CO: Westview, 1993.

Special Issue: Evolutionary Paradigms in the Social Sciences, International Studies Quarterly, 40, 3, September 1996.

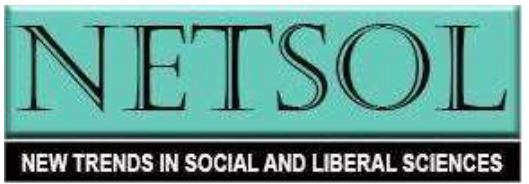


Sriyono, Agus A. "Ethnic nationalism vs. civic nationalism,” Jakarta Post, August 7, 2018.

Staehr, Karsten. "Economic Growth and Convergence in the Baltic States: Caught in a MiddleIncome Trap?" Intereconomics (2015) 50/5: 274-280.

Stalin, J.V. Marxism and the National-Colonial Question. San Francisco: Proletarian Publishers, 1975.

"The economy in the Baltic states keeps growing and here's why." Reinvest 24 (January 21, 2019) at https://blog.reinvest24.com/2019/the-economy-in-the-baltic-states-keeps-growing-andheres-why/

Toynbee, Arnold J. A Study of History, 12 vols. New York: Oxford University Press, 1934-1961.

United Nations Development Programme, Human Development Report 2019: http://hdr.undp.org/sites/default/files/hdr2019.pdf

Vardys, V. Stanley and Judith B. Sedaitis. Lithuania: The Rebel Nation. Boulder, CO.: Westview, 1997.

West, Geoffrey, Scale: The Universal Laws of Growth, Innovation, Sustainability, and the Pace of Life in Organisms, Cities, Economics, and Companies. New York: Penguin, 2017.

Wilson, Edward O. Consilience: The Unity of Knowledge. New York: Knopf, 1998.

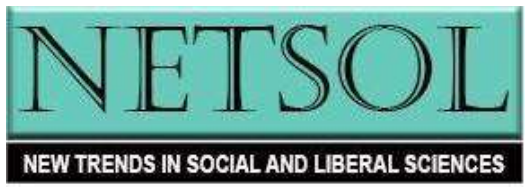

